the relations of these two rocks, noting especially whether, as in the above instances, the gabbro is the newer rock.

Another point of interest in connexion with these serpentines and gabbros is that they are, beyond doubt, of late Cretaceous or early Tertiary age, ${ }^{1}$ and yet are practically identical with serpentines and gabbros which are almost as certainly of Palæozoic age.

\title{
INOTICFS OF MFMOIRS.
}

\section{I.-A New Jurassic Mammat. By Professor O. C. Marsh.}

(From the American Journal of Science and Arts, vol. xviii. July, 1879.)

URING a recent visit to the Rocky Mountains the writer spent some time in examining the deposits known as the Atlantosaurus beds, and was rewarded by the discovery of several interesting fossils, among them the lower jaw of a small mammal. This specimen indicates a diminutive marsupial, quite distinct from the one previously described by the writer from the same horizon (Dryolestes priscus), ${ }^{2}$ which has hitherto been the only mammal known from the Jurassic of this country.

The present specimen, which is from the left side, has the larger part of the ramus preserved, with a number of perfect teeth in position. Most of the symphysial portion is lost, and the posterior part is missing, or only faintly indicated. The jaw was remarkably long and slender. The horizontal portion is of nearly equal depth throughout, and the lower margin nearly straight. The form of the coronoid process, condyle, and angle of the jaw cannot be determined from this specimen. The remarkable feature in this jaw is the series of premolar and molar teeth. These were very numerous, apparently as many as twelve in all, and possibly more. The premolars had their crowns more or less compressed, and recurved, and some of them were supported by two fangs. These had a small posterior tubercle at the base of the crown, but none in front. The molar teeth were all single-fanged, with elevated conical crowns. Those preserved have a distinct cingulum. The molars increase in size from the first to the fifth. All the teeth preserved have the crowns raised considerably above the upper margin of the jaw, and thus appear to be loosely inserted. A large pointed tooth lying near the jaw appears to be a canine. The principal dimensions of this specimen are as follows:

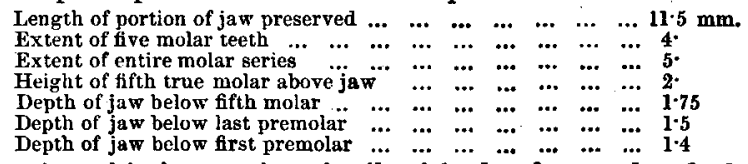

In comparing this interesting fossil with the forms already known, it is at once evident that it differs widely from any living type. Its

1 Jervis, Quart. Journ. Geol. Soc. vol. xvi. p. 480, states that the "diallagic serpentine" pierces the Upper Cretaceous but not the Tertiary rocks. Stoppani, Corso di Geologia, vol. iii. $\$ 704$, places it, if I rightly understand, at about the same period. Both speak of a compact serpentine "without diallage," of Miocene age. This I have not seen. See also D Achiardi, vol. ii. p. 181.

2 Silliman's Journal, vol. xv. p. 459, June, 1878. 
nearest affinities are clearly with the genus Stylodon of Owen, from the * Purbeck beds of England, ${ }^{1}$ and in many respects the correspondence is... close: This specimen clearly indicates a new genus, which may be called Stylacodon, and the species represented, Stylacodon gracilis. With the genus Stylodon, this form evidently constitutes a distinct family, which may appropriately be terned the Stylodontide. The present specimen indicates an animal somewhat smaller than a weasel, and probably insectivorous in habit.

\section{II.-On the Fossil and Recent Sequoles. By Prof. Oswald}

HeEr. (Proceed. Inper. Geol. Instit. Vienna, March 4, 1879.)

NWO species of Sequoia have survived to the present time, namely,

1. Sequoia sempervirens, Endl. (Taxodium sempervirens, Lamb.), still frequent, with distichous, divaricated leaves, small globular fruit, and similar in habit to Taxus baccata: 2. Sequoia gigantea, Endl. (Wellingtonia gigantea, Lindley), only in isolated groups, with narrow leaves, adpressed to the branches, with much larger oviform fruit, and showing the habit of Cupressus. Each of these species represents a distinct type.

The Tertiary species are very numerous. Sequoia brevifolia, Heer, is analogous to $\mathcal{S}$. sempervirens, as $\mathbb{S}$. (Araucarites) Sternbergi, Goepp., is to $S$. gigantea. The Miocene species-S. Langsdorfii (Brongn.), S. brevifolia, H., S. disticha; H., S. Nordenskioldi, H., S. longifolia, Lesq., S. angustifolia, Lesq., and $S$. acuminata, Lesq., are closely related to each other. The interval between the two extreme forms, S. Langsdorfi and S. Sternbergi, is filled up by six species-S. Couttsia, H., S. affinis, Lesq., S. imbricata, H., S. Sibirica, H., S. Heeri, Lesq., and $S$. biformis, Lesq.

Of the ten Cretaceous species, three are of the Upper, two of the Middle, and five of the Lower Cretaceous series. These last have representatives in the two living forms: $\mathcal{S}$. Smittiana, H., in $S$. sempervirens, and $S$. Reichenbachi (Gein.), (Geinitzia cretacea) in $S$. gigantea. The intermediate species are S. subulata, H., S. rigida, H., S. gracilis, H., S. fastigiata, and S. Gardneriana, Carr.; the last three have adpressed leaves.

The Jurassic strata, rich as they are in Coniferous plants, offer no traces of Sequoia, which appears first in the Urgonian beds, -and then in the two extreme forms which have alone survived beyond the Tertiary Period.

Prof. O. Heer also remarks, with regard to the Arctic Tertiary flora, that Mr. J. Starkie Gardner's statement-that two fossil floræ very similar one to the other, but situated under widely distant latitudes, should not be considered to be coëval-is not consistent with the fucts-that living plants (especially trees) are met with from the Italian frontier up to $70^{\circ} \mathrm{N}$. Lat., - that the existing flora of Grinell Land numbers among its 59 phanerogams 45 European and 6 Italian species,-and that of the 559 phanerogamous species of the Island of Saghalin, no less than 188 are found among the flora of Switzerland. The Tertiary flora of the Arctic zone cannot be Eocene, as supposed by Mr. Gardner, for in Northern Bohemia the Cretaceous strata are

${ }^{1}$ Geot. MaG. Vol. III. p. 199, 1866, and Pal. Soc. vol. xxiv. p. 45, 1871. 
succeeded by the Brown-coal series, the oldest horizon of which is decidedly Middle Oligocene; and the Eocenes, strictly so called, are wanting there. The whole discussion, adds Prof. Heer, proves the necessity of ascertaining with more precision the age and geological position of the Tertiary floræ in each locality. At all events, the present exact knowledge of the North-Polar Tertiary floræ, he says, has been highly profitable to Geology in proving the needlessness of the hypothesis of a formerly existing "Atlantis."

T. R. J.

\section{卫}

I. - Notes on Crystallography and Crystallo-physics. By Jonn Mirne, F.G.S. (Professor of Geology and Mineralogy in the Imperial College of Engineering, Yedo, Japan.) 8vo. pp. 80 ; 25 Woodcuts. (London: Trübner \& Co., 1879.)

ПHE study of Geology is a wide one, implying a foreknowledge 1 of Biology, Chemistry, Physics, and Mineralogy, and to be well acquainted with all these is rarely the lot of one man; therefore, when a geologist writes a book on Crystallography and Crystallophysics, it is apparent that there must be a considerable want felt by geologists for a work of this kind, viz. one which, while deserting the awkward system of Naumann still taught in preference to any other by several of our teachers of mineralogy, and using the elegant system of Neumann and Miller, yet attempts (to use Mr. Milne's own words) " to give the general principles which crystallographical calculations involve for the use of those students who wish to know them, rather than for those who wish actually to employ them "

It is to be regretted (for the sake of the author) that the publication of Mr. Milne's Crystallography was delayed, owing to bis absence from England, as, when the lithographed notes of these lectures delivered in Japan were sent to England for publication "in the Geological Magazine, or elsewhere," Mr. Gurney's little book on Crystallography had not yet appeared. Had they been printed in this conntry earlier, they would have taken precedence in publication of $\mathrm{Mr}$. Gurney's pamphlet, as they undoubtedly do in date of issue in Japan.

The author expresses himself indebted for information to Prof. Miller's Treatise on Crystallography, and Prof. Maskelyne's Iuecturenotes on the Morphology of Crystals; he might also have cited Prof. Miller's Tract on Crystallography, which, though shorter, is preferable to his Treatise, at least from a mathematician's point of view.

Important as the study of Lithology has now become to geologists, we hope to see Mineralogy studied by them in a truly scientific manner, and this work we take as an indication that this has begun. Whilst taking exception to the way in which Mr. Milne has tried to avoid some of the difficulties of the subject-as on page 16, where the proof given applies only to those crystals belonging to four out of the six existing systems, and the results of which are used on page 25 in dealing with a crystal belonging to one of the two excluded systems-we cannot but admire his courage in 